\title{
Nox4-Generated Superoxide Drives Angiotensin II-Induced Neural Stem Cell Proliferation
}

\author{
Elena Topchiy ${ }^{\mathrm{a}}$ Evgeniy Panzhinskiy ${ }^{\mathrm{a}}$ W. Sue T. Griffin ${ }^{\mathrm{a}}$ b Steven W. Barger ${ }^{\mathrm{a}}$ b \\ Mita Das ${ }^{c}$ W. Michael Zawada ${ }^{a}$ \\ ${ }^{a}$ Department of Geriatrics, The Reynolds Institute on Aging, ${ }^{b}$ GRECC, Central Arkansas Veterans Health System, \\ and ${ }^{\mathrm{C}}$ Division of Gastroenterology and Hepatology, Department of Internal Medicine, University of Arkansas for \\ Medical Sciences, Little Rock, Ark., USA
}

\section{Key Words}

Angiotensin II $\cdot$ C17.2 cells $\cdot$ NADPH oxidase .

Neuroinflammation · Neurogenesis · Parkinson's disease ·

Reactive oxygen species

\section{Abstract}

Reactive oxygen species (ROS) have been reported to affect neural stem cell self-renewal and therefore may be important for normal development and may influence neurodegenerative processes when ROS activity is elevated. To determine if increasing production of superoxide, via activation of NADPH oxidase (Nox), increases neural stem cell proliferation, $100 \mathrm{nM}$ angiotensin II (Ang II) - a strong stimulator of Nox - was applied to cultures of a murine neural stem cell line, C17.2. Twelve hours following a single treatment with Ang II, there was a doubling of the number of neural stem cells. This increase in neural stem cell numbers was preceded by a gradual elevation of superoxide levels (detected by dihydroethidium fluorescence) from the steady state at 0 , 5 , and $30 \mathrm{~min}$ and gradually increasing from $1 \mathrm{~h}$ to the maximum at $12 \mathrm{~h}$, and returning to baseline at $24 \mathrm{~h}$. Ang Il-dependent proliferation was blocked by the antioxidant $\mathrm{N}$-acetyl-L-cysteine. Confocal microscopy revealed the presence of two sources of intracellular ROS in C17.2 cells: (i) mitochondrial and (ii) extramitochondrial; the latter indicative of the involvement of one or more specific isoforms of Nox. Of the Nox family, mRNA expression for one member, Nox4, is abundant in neural stem cell cultures, and Ang II treatment resulted in elevation of the relative levels of Nox4 protein. SiRNA targeting of Nox4 mRNA reduced both the constitutive and Ang II-induced Nox4 protein levels and attenuated Ang II-driven increases in superoxide levels and stem cell proliferation. Our findings are consistent with our hypothesis that Ang II-induced proliferation of neural stem cells occurs via Nox4-generated superoxide, suggesting that an Ang II/Nox 4 axis is an important regulator of neural stem cell self-renewal and as such may fine-tune normal, stress- or disease-modifying neurogenesis.

Copyright @ 2013 S. Karger AG, Basel

\section{Introduction}

Neural stem cells give rise to all the neurons, astrocytes, and oligodendrocytes in the mammalian central nervous system (CNS) via generation of intermediate progenitors capable of phenotypic differentiation [1].

\section{KARGER}

E-Mail karger@karger.com

www.karger.com/dne
(C) 2013 S. Karger AG, Basel

$0378-5866 / 13 / 0354-0293 \$ 38.00 / 0$
W. Michael Zawada, PhD

University of Arkansas for Medical Sciences

The Reynolds Institute on Aging, Department of Geriatrics

629 Jack Stephens Drive, Room 4122, Little Rock, AR 72205 (USA)

E-Mail wzawada@uams.edu 
Formation of the highly complex CNS is dependent on closely regulated developmental generation, differentiation, and migration of new neurons (neurogenesis). Although neurogenesis in the mammalian brain declines with age, in the adult, neural stem cells are present in a few specific neurogenic zones such as the dentate gyrus and the subventricular zones of the lateral ventricles [2, $3]$. The process of self-renewal and maintenance of pools of undifferentiated stem cells, via symmetric and asymmetric cell division, is one of two key characteristics of stemness; the other is potency, which in the case of multipotent neural stem cells enables their differentiation into all three major neural cell types [1]. Cell division during self-renewal is controlled by numerous factors acting in location-, circumstance-, and time-dependent modes. Some factors are engendered intrinsically, for example epigenetically [4]. Others are extrinsic, for example in vitro stimulation of neural stem cells with growth factors, such as fibroblast growth factor 2 [5] and epidermal growth factor [6], which trigger downstream signaling pathways that lead to proliferation and activation of transcription factors. One such factor, Notch, which supports propagation and stemness of neural stem cells, is a case in point [7].

Many methods for inducing and maintaining stem cell self-renewal have been described, but details regarding specific mechanisms that orchestrate self-renewal patterns of stemness in varying circumstances remain unclear. To delve deeper into such mechanisms, we have examined the hypothesis that angiotensin II (Ang II) activates a specific NADPH oxidase (Nox) isoform to regulate self-renewal in neural stem cells. We chose Ang II because (i) neurospheres composed of neural progenitors derived from the midbrain respond to Ang II by favoring progenitor differentiation into dopamine neurons [8] and because (ii) studies of vascular smooth muscle cell cultures showed that treatment with Ang II resulted in Nox-mediated generation of superoxide and induction of proliferation [9]. Further support for our hypothesis comes from a study using a pharmacological inhibitor of Nox, apocynin, which attenuated proliferation of cultured embryonic hippocampal neural stem cells/progenitors, suggesting that reactive oxygen species (ROS)-mediated regulation of stemness might be important for the maintenance of the hippocampal neurogenic niche [10]. The human genome contains seven members of the Nox family. The members include Nox $1-5$ as well as Duox1 and 2, the latter two being two dual oxidases containing both Nox and peroxidase-like domains [11, 12]. Relevant to this report, the gene encoding Nox 5 is not present in rodents [13] and the tissue distribution of the Nox family members varies considerably [12]. The Nox4 isoform of Nox was discovered by Geiszt et al. [14] and its function depends on Nox4 catalytic center transferring electrons from NADPH to oxygen to form superoxide [15]. Although the majority of the studies have examined Nox4 in the vascular, cardiac, and renal systems [16], we focused on its effects in the brain [17], and recently on its modus operandi within neural stem cell niches.

Here, we report three novel findings regarding actions of Ang II on neural stem cells in culture. Chronologically we found that (i) Ang II increases the number of such cells, (ii) this is via production of superoxide, and (iii) which was generated by Nox4.

\section{Methods}

\section{Cell Culture}

All experiments were conducted using a $v$-myc-immortalized, $\beta$-galactosidase-expressing, C17.2 clone of a neural stem cell line originally derived from the external germinal layer of neonatal mouse cerebellum [18]. Reagents were purchased from SigmaAldrich, St. Louis, Mo., USA, unless specified otherwise. C17.2 cells were cultured at a density of $1.2 \times 10^{4}$ cells $/ \mathrm{cm}^{2}$ in Dulbecco's modified Eagle's medium (DMEM; Invitrogen, Carlsbad, Calif., USA) supplemented with $10 \%$ fetal bovine serum (FBS), $5 \%$ horse serum (Invitrogen), $2 \mathrm{mM}$ L-glutamine, $100 \mathrm{U} / \mathrm{ml}$ penicillin, and $100 \mu \mathrm{g} / \mathrm{ml}$ streptomycin in $5 \% \mathrm{CO}_{2}$ at $37^{\circ} \mathrm{C}$. Cultures were grown either in 96-well plates or T25 and T75 culture flasks. The medium was changed every $2-3$ days and cells were passaged by first being detached from the dish in $0.05 \%$ trypsin-EDTA and then subcultured at a ratio of 1:10. Only cells from passages 6-11 were used. Prior to initiating any experiments, media were changed to $0.1 \%$ FBS containing medium for $48 \mathrm{~h}$, to create near serum-free culture conditions. For experiments examining ROS involvement, cells were pretreated with $\mathrm{N}$-acetyl-L-cysteine (NAC) for $1 \mathrm{~h}$ or pretreated for $6 \mathrm{~h}$ with two inhibitors of Nox, apocynin and phenylarsine oxide (PAO) before stimulation with Ang II began. The murine aortic smooth muscle cell line, MOVAS (American Type Culture Collection, Manassas, Va., USA), a control cell line for the RT-PCR experiments, was grown under identical conditions as the C17.2 cells.

\section{Quantification of Cell Numbers and Proliferation}

Cells were plated in 96-well plates and after $48 \mathrm{~h}$ of growth arrest in $0.1 \%$ FBS-containing medium were treated with Ang II (100 $\mathrm{nM}$ ) and cultured for an additional 24 or $48 \mathrm{~h}$. Cell numbers were determined hemocytometrically and proliferation was estimated using the manufacturer's protocol for CellTiter $96^{\circledR} \mathrm{AQ}_{\text {ueous }}$ One Solution Cell Proliferation Assay (Promega, Madison, Wisc., USA), which measures mitochondrial activity. Additionally, proliferation was also demonstrated by measuring the de novo DNA synthesis as a function of 5-bromo- $2^{\prime}$-deoxyuridine (BrdU) incorporation into newly synthesized DNA using BrdU Cell Prolifera- 
tion ELISA Kit (Abcam, Cambridge, Mass., USA) according to the manufacturer's protocol.

\section{Intracellular Superoxide Measurement}

Intracellular superoxide levels were determined using $10 \mu \mathrm{M}$ dihydroethidium, which is oxidized by superoxide to form ethidium bromide (DHE; Invitrogen) for identification of sites at which superoxide is present [19]. To determine the time-course of Ang II-induced superoxide generation, Ang II (100 nM) was added to cultures, and superoxide levels were determined at 5 and $30 \mathrm{~min}$, and $1,3,6,12$, and $24 \mathrm{~h}$. Cells were incubated with DHE for $30 \mathrm{~min}$ prior to termination of each experiment, at which point incubation medium was removed, cultures were washed twice with PBS, and fluorescence was detected on a SpectraMax Gemini XS microplate spectrofluorometer (Molecular Devices, Sunnyvale, Calif., USA) at excitation of $488 \mathrm{~nm}$ and emission of $610 \mathrm{~nm}$.

\section{Cell Imaging}

For cell morphology comparisons, C17.2 cells were plated at the same density and cultured in $0.1 \%$ serum for $48 \mathrm{~h}$. Cells were observed with a Leica DMI 3000B microscope (Leica, Bannockburn, Ill., USA) at $\times 400$ magnification and phase contrast and fluorescence images of cultured cells were acquired using SPOT CCD camera (SPOT Diagnostics, Sterling Heights, Mich., USA). In experiments using DHE, a direct comparison of the fluorescence intensity of each culture was possible because images were obtained under identical illumination and exposure conditions in each experiment. Superoxide was quantified by detecting red fluorescence of the oxidized (dehydrogenated) DHE product, ethidium bromide (excitation/emission: 518/605 nm) following DHE entry into the cytoplasm where it is oxidized by superoxide. Sites of intracellular superoxide generation (inside or outside of the mitochondria) in C17.2 cells were identified by performing dual labeling of live C17.2 cells with $10 \mu \mathrm{M}$ DHE and $100 \mathrm{nM}$ MitoTracker Green FM Dye (excitation/emission: 490/516 nm; Invitrogen) according to the manufacturer's protocol. MitoTracker is a dye that selectively accumulates inside active mitochondria. Cells were preloaded with a combination of DHE and MitoTracker Dye in DMEM for $30 \mathrm{~min}$ at $37^{\circ} \mathrm{C}$. Cellular structure within C17.2 stem cells was visualized with a fluorescent vital dye, which labels tubulin [Tubulin Tracker Green (excitation/emission: 494/522 nm; Invitrogen)], and recorded during a 5-min interval using time-lapse video screening. Images of the cultures $(\times 200$ magnification), preloaded with DHE and Tubulin Tracker followed by fresh medium, were acquired using a Zeiss 710 confocal microscope equipped with an AxioCam HR camera (Zeiss) and ZEN software.

\section{PT-PCR}

Total RNA was isolated from C17.2 cells with TRIzol reagent as described by the supplier (Invitrogen). Copy DNA was transcribed from $1 \mu \mathrm{g}$ of total RNA using the Quantiscript Reverse Transcriptase kit (Qiagen, Valencia, Calif., USA). The following PCR conditions were used sequentially: 1 cycle at $94^{\circ} \mathrm{C}$ for $5 \mathrm{~min}, 40$ cycles at $94^{\circ} \mathrm{C}$ for $15 \mathrm{~s}$ (denaturation), $60^{\circ} \mathrm{C}$ for $30 \mathrm{~s}$ (annealing) and $72^{\circ} \mathrm{C}$ for $80 \mathrm{~s}$ (elongation), and one cycle at $72^{\circ} \mathrm{C}$ for $5 \mathrm{~min}$ as the final elongation step. The primers (Invitrogen) were: Nox2, forward 5'-CGAAGACAACTGGAAGGAA-3' (amplicon 956 bp) and reverse $5^{\prime}$-GCTCCCACTAACATCACCAC- $3^{\prime}$; Nox3, forward 5'-TTGTGGCACACTTGTTCAAACCTGG-3' (amplicon 493 bp) and reverse $5^{\prime}$-TCACACGCATACAAGACCACAGGA-3'; Nox4, forward $5^{\prime}$-ATCACAGAAGGTCCCTAGCA-3' (amplicon 615 bp) and reverse 5'-GGTCCAGAAATCCAAATCCA-3'; Duox1, forward $5^{\prime}$-CACCATTGGGACCCTTTGCTGTTT-3' (amplicon $761 \mathrm{bp}$ ) and reverse $5^{\prime}$-AGCCTTTCATGAAGACCACCAGAA-3', and Duox 2 , forward $5^{\prime}$-AACCACCTATGTGGGCATCATCCT-3' (amplicon $491 \mathrm{bp}$ ) and reverse 5'-AGCTGCCATGGATGATGATCAGGA-3'. Glyceraldehyde 3-phosphate dehydrogenase (GAPDH) was amplified as a housekeeping control using the following primers: forward 5'-TCGACAGTCAGCCGCATCTTCTTT-3' (amplicon $351 \mathrm{bp}$ ) and reverse $5^{\prime}$-ACCAAATCCGTTGACCTT-3'. PCR products were separated on a $1 \%$ agarose gel and ethidium bromide-stained amplicons were visualized under UV light.

\section{Western Immunoblotting}

Cells were homogenized on ice with cell lysis buffer supplemented with a phosphatase inhibitor (Thermo Scientific, Barrington, Ill., USA) and protease inhibitor. Homogenates were centrifuged at $10,000 \mathrm{~g}$ at $4^{\circ} \mathrm{C}$ for $10 \mathrm{~min}$ to remove cell debris. The protein concentration of the resulting supernatant was determined using Bradford reagent (Bio-Rad Laboratories, Hercules, Calif., USA). Proteins and prestained molecular weight protein standards (Bio-Rad Laboratories) (40 $\mu \mathrm{g})$ were separated on $4-12 \%$ gradient Bis-Tris gels in MOPS SDS Running buffer (Invitrogen) and transferred to PVDF membranes (GE Water \& Process Technologies, Trevose, Pa., USA). The PVDF membranes were blocked with 5\% BSA in Tris-buffered saline (TBS) containing 0.05\% Tween-20 (TBST) for $1 \mathrm{~h}$ at $20^{\circ} \mathrm{C}$, washed with TBST, and probed with a primary polyclonal rabbit anti-Nox4 antibody (ab60940; 1:650; Abcam) diluted in blocking buffer overnight at $4{ }^{\circ} \mathrm{C}$. The washed membrane was incubated for $1 \mathrm{~h}$ at $20^{\circ} \mathrm{C}$ with a secondary antirabbit antibody diluted in blocking buffer $1: 10,000$ for $2 \mathrm{~h}$ at $20^{\circ} \mathrm{C}$. Antibody labeling was visualized using chemiluminescent reagent Lumi-Phos WB (Thermo Scientific, Waltham, Mass., USA).

\section{RNAi Targeting of Nox4}

Cells were plated in 96-well plates at a density of $4 \times 10^{3}$ cells/ well and allowed to grow for $48 \mathrm{~h}$ in complete growth medium as described above. For cell growth arrest, medium was replaced with medium containing $0.1 \%$ FBS. After $24 \mathrm{~h}$ of growth arrest, cell transfection was performed using TransIT-TKO (TKO) transfection reagent (Mirus, Madison, Wisc., USA) according to the manufacturer's protocol. After transfection, $100 \mathrm{nM}$ Ang II was either immediately added to the medium or added at $36 \mathrm{~h}$ and all were assayed, at $48 \mathrm{~h}$ after transfection, for Nox 4 by Western blotting (12 h after Ang II), for superoxide generation by DHE (12 h after Ang II), and for cell proliferation by mitochondrial activity levels (48 h after Ang II). To confirm specificity of siRNAs, cell lysates were collected $48 \mathrm{~h}$ after transfection and immunoreacted with Nox4 antibody. To determine the most efficacious siRNA, three different siRNA duplexes targeting murine Nox4 were tested and all three were shown to be effective at reducing expression of Nox4 as assayed by Western immunoblot. Nox4 siRNA duplex \#1 containing sense (5'-CAAGAAGAUUGUUGGAUAAUU- $\left.3^{\prime}\right)$ and antisense $\left(5^{\prime}\right.$-UUAUCCAACAAUCUUCUUGUU- $\left.3^{\prime}\right)$ sequences was chosen for the studies reported here because of the three Nox4 siRNAs tested it was most efficacious. For controls, we used the following three conditions: (i) medium change only - no TKO transfection reagent and no siRNA, (ii) medium containing TKO, but without any siRNA, and as a negative control siRNA, (iii) medium with On-target plus \#2 control nontargeting siRNA [Scram- 


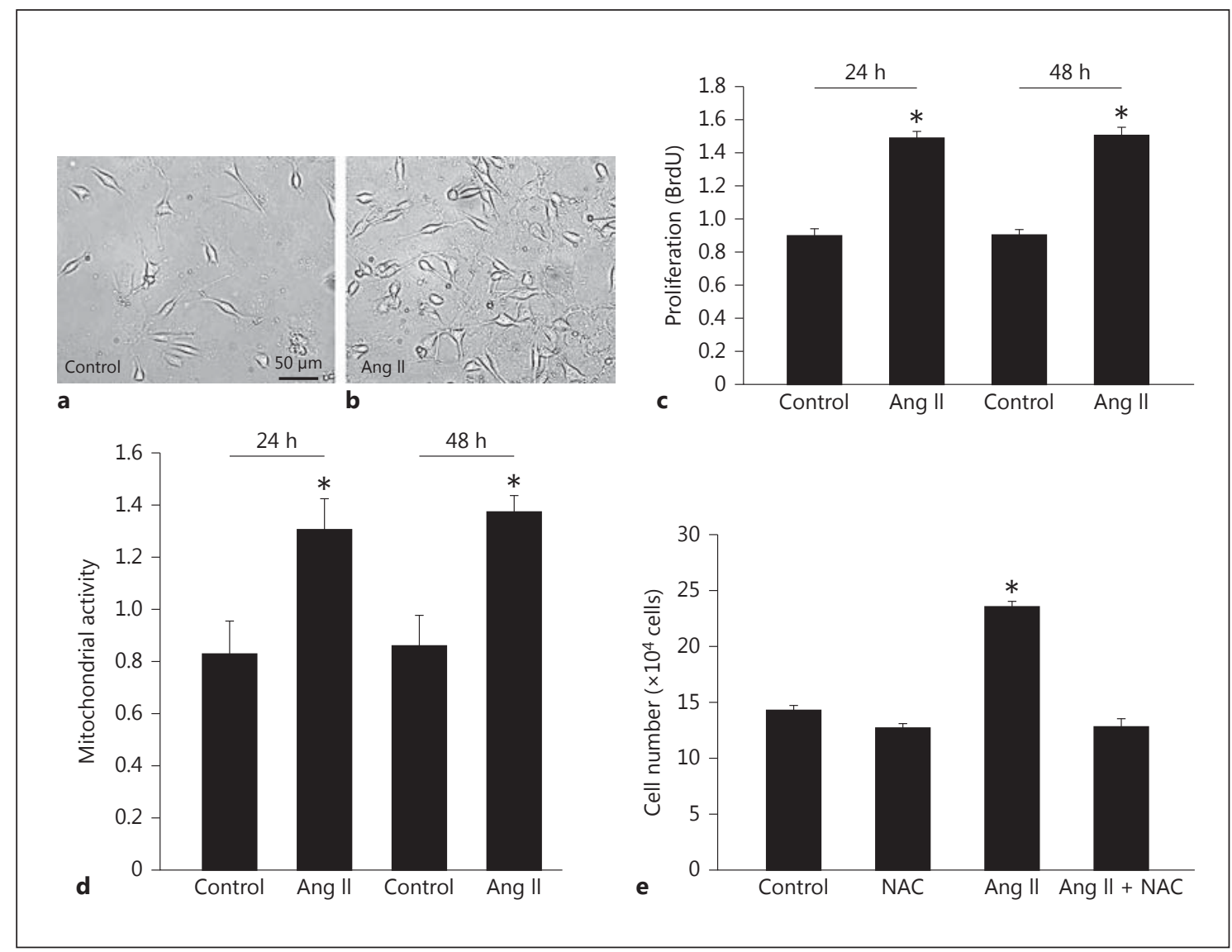

Fig. 1. Ang II increases stem cell proliferation. a, b Bright-field photomicrographs of C17.2 stem cell cultures grown for $12 \mathrm{~h}$ in the absence (a) or presence (b) of $100 \mathrm{nM}$ Ang II. At $12 \mathrm{~h}$ posttreatment (b), there was an obvious increase in the numbers of cells. c The BrdU Cell Proliferation ELISA Kit, which detects newly synthesized DNA, confirmed a significant elevation in cell proliferation (BrdU incorporation) in response to Ang II resulting in higher cell numbers 24 and $48 \mathrm{~h}$ after a single treatment with Ang II. d The CellTiter $96 \mathrm{AQ}_{\text {ueous }}$ One Solution Cell Proliferation Assay, which

bled (SCR) siRNA], containing at least 4 mismatches to any human, mouse, or rat genes. Based on data from microarray analysis, this SCR siRNA does not target any genes in these three species. All siRNA duplexes were purchased from Thermo Scientific/ Dharmacon (Waltham, Mass./Lafayette, Colo., USA).

\section{Data Analysis}

All data are expressed as arithmetic means \pm SEM. Statistical analysis was performed using one-way analysis of variance (ANOVA) followed by a Student-Newman-Keuls post hoc test for multiple comparisons between groups of data points. Student's t test was used when appropriate. Data were considered significantly different if the $p$ value was $\leq 0.05$. measures mitochondrial function, detected increases in mitochondrial activity with Ang II treatment. ${ }^{*} \mathrm{p}<0.001$ (c) and $\mathrm{p}<0.05$ (d) compared to control cultures. e Hemocytometric cell counts at $48 \mathrm{~h}$ validated the observation of an Ang II-driven proliferative response. In addition, an antioxidant (NAC) prevented Ang IIinduced proliferation. ${ }^{*} \mathrm{p}<0.05$ compared to control, NAC, and Ang II + NAC cultures. Data are from three independent experiments with 6 wells per experiment.

\section{Results}

\section{Role of Ang II and ROS in Neural Stem Cell Proliferation}

There were noticeably higher numbers of cells $12 \mathrm{~h}$ following a one-time Ang II (100 nM) treatment of growtharrested C17.2 cells than there were in untreated sister cultures (fig. 1a, b). In addition, a Cell Proliferation Assay assessment of cell numbers based on cellular mitochondrial activity showed a $1.7 \times$ increase $(\mathrm{p}<0.05)$ in the number of viable cells (fig. $1 \mathrm{~d})$ and a $1.7 \times$ increase $(\mathrm{p}<0.001)$ in BrdU incorporation (fig. 1c) following a 24-hour treatment with Ang II. These increases persisted unchanged at 


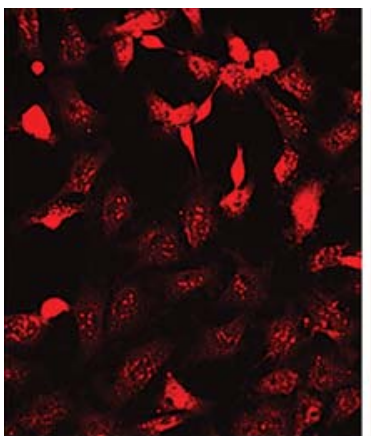

a

$0 \min$

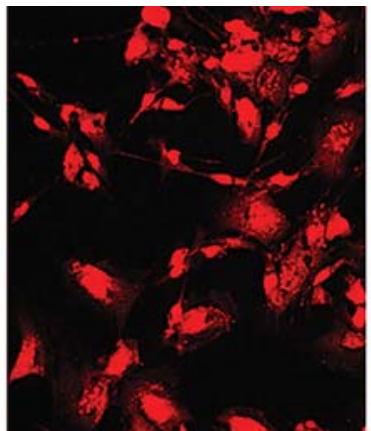

$1 \mathrm{~h}$

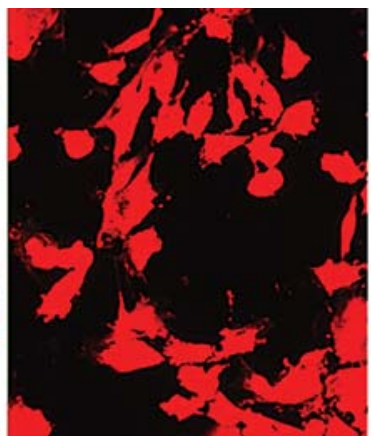

$12 \mathrm{~h}$

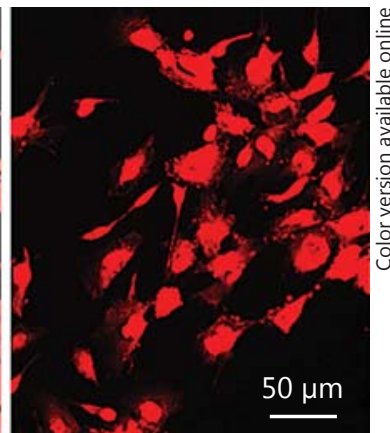

$24 \mathrm{~h}$

Fig. 2. Ang II drives superoxide generation in a time-dependent manner. The increase in superoxide was assessed by (a) microscopic and (b) microplate DHE assay of the fluorescent product of DHE oxidation. $* \mathrm{p}<0.05$ compared to $0,5,30 \mathrm{~min}$, and 24 h. ${ }^{\#} \mathrm{p}<0.05$ compared to $0,5,30 \mathrm{~min}$, and 1 and $24 \mathrm{~h}$. Data are from three independent experiments with 6 wells per experiment.

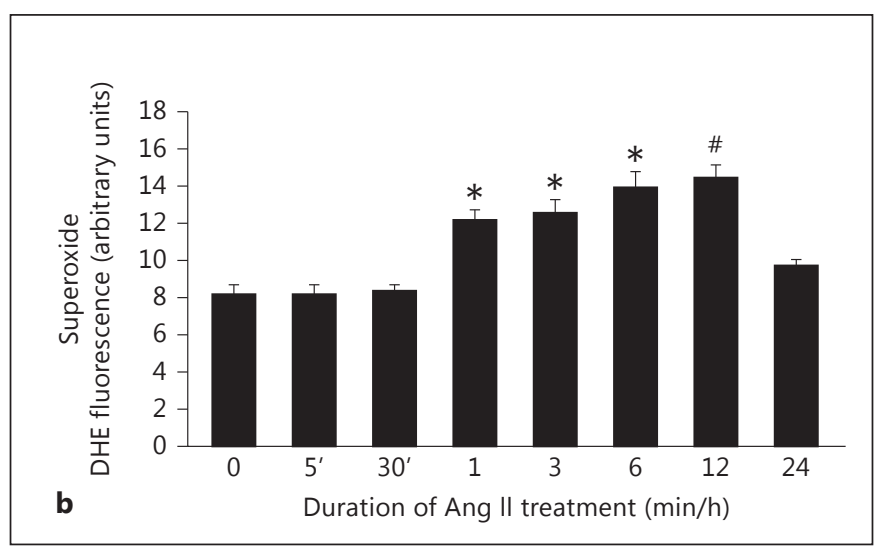

$48 \mathrm{~h}$ following Ang II treatment (fig. 1c, d). The lack of cell division between 24 and $48 \mathrm{~h}$ was to be expected, as the cultures were grown in near serum-free conditions $(0.1 \%$ serum) for $48 \mathrm{~h}$ prior to addition of Ang II, a growth-arrested condition under which cells dramatically slow down their division eventually ceasing to divide. Together, the results of the Cell Proliferation Assay combined with the finding of an Ang II-induced increase in BrdU incorporation give credence to the existence of Ang II-driven proliferative responses in neural stem cell cultures. This Ang II-induced C17.2 neural stem cell proliferation was shown to be a result of superoxide generation as a 1-hour pretreatment of cultures with the antioxidant, NAC before adding Ang II resulted in an abrogation of the elevation in cell numbers (fig. 1e), implicating Ang II in initiation of a signaling cascade that depends on superoxide for its stimulatory effects on proliferation. This NAC abrogation of Ang II-induced proliferation of C17.2 suggests that Ang II binding to the Ang II type 1 receptor (AT1R) is important in Nox induction of superoxide as previously shown in proliferation of kidney cell cultures [20].

Intracellular superoxide in resting (untreated) C17.2 cells as illustrated by DHE fluorescence labeling is detect- able, but minimal relative to that following Ang II treatment (fig. 2a). Superoxide levels, as observed by DHEfluorescence microscopy, showed that with a 1-hour Ang II treatment, most of the C17.2 cells had a visibly brighter superoxide-detecting DHE signal. This signal reached a zenith at $12 \mathrm{~h}$, and returned to baseline by $24 \mathrm{~h}$ (fig. $2 \mathrm{a}$ ). Measurement of DHE fluorescence in sister cultures confirmed these microscopic observations (fig. 2b). Compared to cultures that were untreated, or were treated for 5 or $30 \mathrm{~min}$, a 1-hour Ang II treatment resulted in a 1.5x increase in superoxide levels $(\mathrm{p}<0.05)$. There was a gradual increase to $1.8 \times$ between 1 and $12 \mathrm{~h}$ of Ang II treatment $(\mathrm{p}<0.05)$. Superoxide levels returned to baseline at $24 \mathrm{~h}$ posttreatment with Ang II, perhaps due to a reduction in substrate or availability or activity of superoxidegenerating enzymes.

\section{Nox As a Source of Superoxide in Neural Stem Cells}

Confocal microscopic detection of intracellular superoxide by DHE detection in combination with mitochondrial staining with MitoTracker Green showed that Ang II treatment of C17.2 induced generation of superoxide (red) in mitochondria (green) (fig. 3). Superoxide was co- 


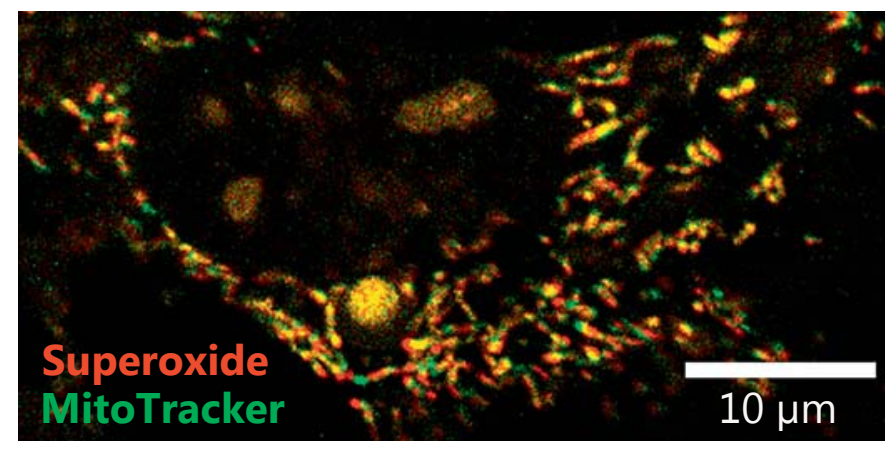

Fig. 3. Superoxide originates inside and outside of mitochondria. When treated with Ang II, neural stem cells generate superoxide (DHE, red) in mitochondria - identified here by MitoTracker Green - as well as at sites, which are extramitochondrial and likely represent membrane-associated Nox as a source of superoxide. As illustrated here, fluorescence in the nucleus represents DHE oxidized to ethidium bromide (a fluorescent nucleic acid stain), which, when generated intracellularly, intercalates into DNA.

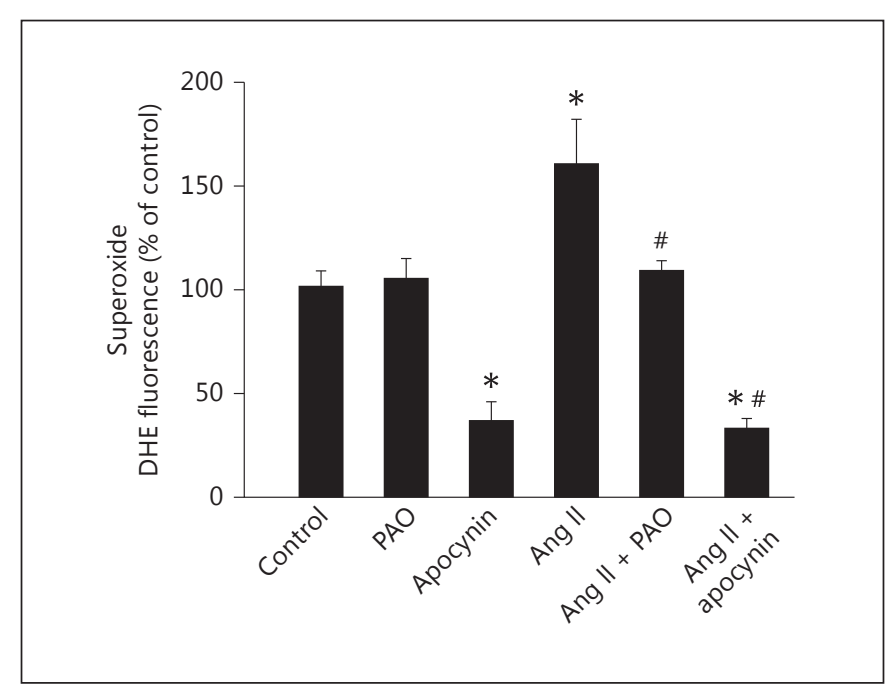

Fig. 4. Superoxide production, generated in response to Ang II, is reduced by inhibitors of Nox such as PAO $(0.6 \mu \mathrm{M})$ and apocynin $(10 \mu \mathrm{M})$. Cultures were pretreated with either PAO or apocynin for $6 \mathrm{~h}$ prior to a 1-hour treatment with Ang II. ${ }^{*} \mathrm{p}<0.05$ compared to control and PAO-treated cultures. ${ }^{\#} \mathrm{p}<0.05$ compared to Ang II-treated cultures. Data are from three independent experiments with 6 wells per experiment.

localized to mitochondria (yellow), suggesting that the Ang II induction of proliferation of C17.2 cells could involve generation of superoxide (DHE) in mitochondria. Extramitochondrial superoxide (red) production was also evident, suggesting that membrane-bound Nox might be another source of superoxide in these cells. The highly dynamic generation of superoxide was shown by time-lapse videography, which revealed changes in superoxide production on a timescale of seconds in mitochondria as well as in extramitochondrial sites in C17.2 stem cells (see suppl. video online; for all online supplementary material, see www.karger.com/doi/10.1159/000350502). These findings are consistent with the idea of an existence of distinct superoxide-generating niches in these stem cells - a system which allows for compartmentalization of superoxide production in mitochondrial and extramitochondrial sites.

ROS induction of proliferation of vascular smooth muscle cells reported by Rao and Berk [21], together with the more recent finding that Nox-generated superoxide induces proliferation of these vascular cells [22], raises the possibility that like vascular smooth muscle cells, neural stem cells utilize a Nox-mediated mechanism to replenish themselves as a stem cell pool. Pursuing this line of thinking, the effects of two inhibitors of Nox, apocynin and PAO, were measured to show that Ang II-induced superoxide generation occurs and that this generation is blocked by apocynin (to $18 \%$ of Ang II) and to a lesser degree by PAO (to 33\% of Ang II) (fig. 4). The observed effectiveness of Nox inhibitor apocynin in reducing the baseline superoxide production in C17.2 cultures predicts the following two associations: (i) at least one of the Nox isoforms is constitutively producing superoxide, that is in the absence of exogenous Ang II, and (ii) treatment of neural stem cells with Ang II activates one or more Nox isoforms for the production of superoxide above the baseline levels. To ensure that the reduction in baseline superoxide is not a result of cell death, we exposed control cultures to $10 \mu \mathrm{M}$ apocynin for $7 \mathrm{~h}$ and observed no change in the numbers of surviving C17.2 cells between control and apocynin-treated cultures (see online suppl. fig. 1S).

\section{Explicit Role for Nox4 As a Driver of Ang II-Induced Proliferation}

The order of abundance of the mRNA expression of Nox family members in C17.2 neural stem cell line was Nox $4>$ Duox $1>$ Nox $3>$ Duox $2>$ Nox 2 (fig. 5a), which is important for our study because of the potential role of Nox-generated superoxide in stem cell proliferation. Therefore, Nox 4 expression was our focus as: (i) Nox4 mRNA in C17.2 is the most common isoform, (ii) Nox4 is an inducible isoform of Nox [23], and (iii) Nox4 is expressed intracellularly in the membranes of the perinuclear endoplasmic reticulum [24], in the nucleus [25] and in the mitochondria [26], suggesting that Nox-mediated 


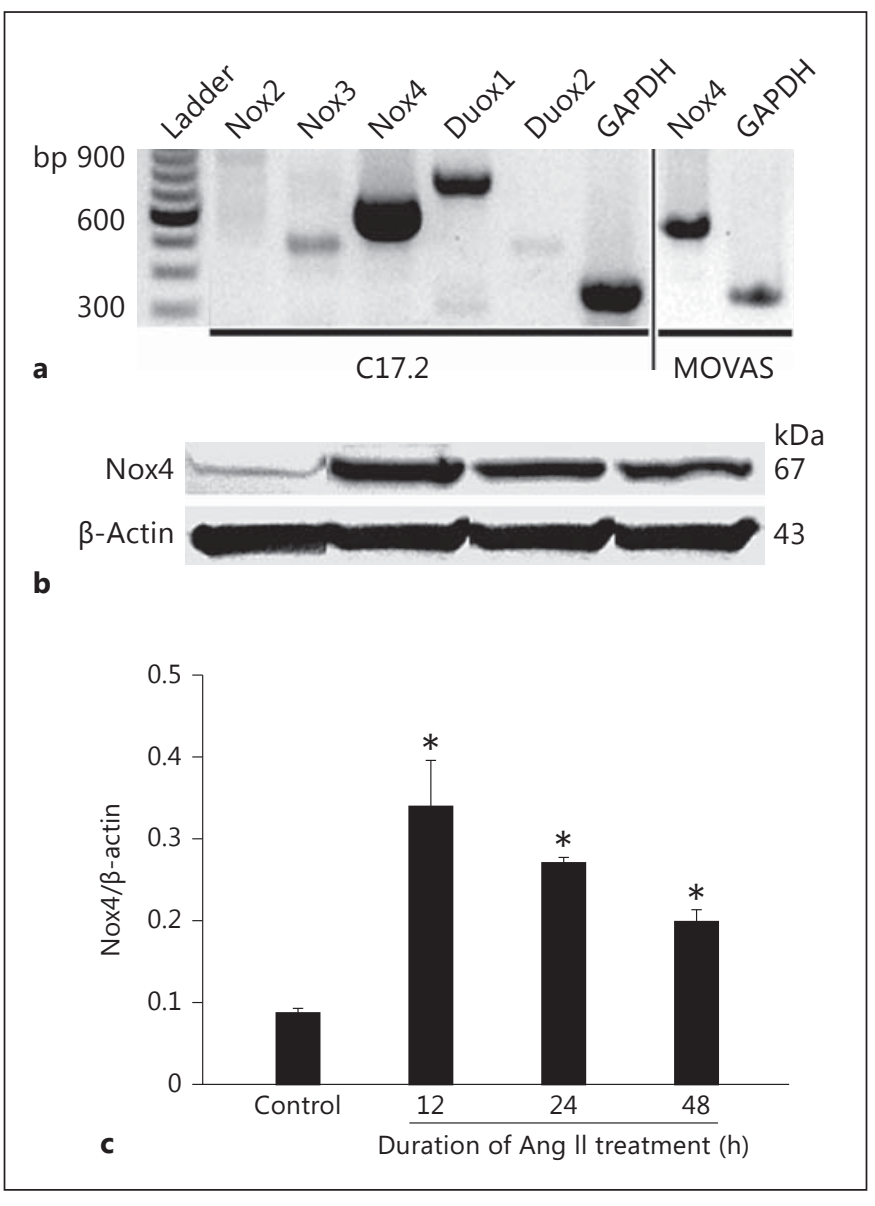

Fig. 5. Nox4 mRNA is the most abundant Nox isoform mRNA in C17.2 cells (a). Murine aortic smooth muscle cell line (MOVAS) was used as a positive control for Nox 4 mRNA expression. Ang II treatment increases Nox4 synthesis as illustrated by (b) Western immunoblot and was quantified densitometrically and analyzed using NIH image J (c). ${ }^{*} \mathrm{p}<0.05$ compared to control cultures, which were not treated with Ang II. Data are from three independent experiments with 6 wells per experiment.

production of superoxide may result in its release directly into specific intracellular compartments. Treatment of C17.2 cultures with Ang II (100 nM) resulted in an increase in the translation of Nox 4 as observed by Western immunoblot (fig. 5b, c). The relative levels of Nox4 protein were significantly elevated by Ang II treatment compared to untreated sister cultures $(\mathrm{p}<0.05)$. Specific increases in Nox 4 protein were $3.4 \times$ at $12 \mathrm{~h}$ of Ang II treatment, $2.8 \times$ at $24 \mathrm{~h}$, and $2.0 \times$ at $48 \mathrm{~h}$.

Silencing Nox4 mRNA with siRNA duplexes showed that de novo synthesis of Nox 4 was suppressed by $67 \%$ $(\mathrm{p}<0.01)$ (fig. 6a, b), while the constitutive superoxide levels (fig. 6c) and proliferation remained unaffected (fig. 6d), suggesting that factors other than Nox4 contribute to superoxide and proliferation. One such factor may be Ang II-induced increases in production of Nox4 protein $(3 \times, \mathrm{p}<0.01)$ (fig. $6 \mathrm{e}, \mathrm{f})$, induction of superoxide $(2 \times$, $\mathrm{p}<0.01$ ) (fig. $6 \mathrm{~g}$ ), and proliferation $(1.5 \times, \mathrm{p}<0.01)$ (fig. 6h). Consistent with the role of Nox4 in Ang II-mediated neural stem cell proliferation, both the $2 \times$ increase in superoxide production in response to Ang II (fig. 6g) as well as the proliferative response to Ang II (fig. 6h) were eliminated in cultures that were treated with Ang II after being transfected with siRNA targeting Nox4.

To our knowledge, the data presented in this report provide the first experimental evidence that the angiotensin system - specifically the octapeptide Ang II - is a key factor in the regulation of self-renewal in neural stem cells through Nox4-mediated production of superoxide. This Ang II upregulation of Nox4 expression and Nox4 generation of superoxide at concentrations which promote stem cell proliferation and thereby support the renewal of the stem cell pool is conceptualized in figure 7.

\section{Discussion}

Healthy brain function requires that a subpopulation of neural stem cells is maintained in undifferentiated pools. This status quo exerts key influence in brains undergoing development, modifies brain functions via the process of neuroplasticity, and may respond to cellular stress in neurological diseases. The mechanisms safeguarding maintenance of such pools are complex, because each neurogenic niche is controlled by factors such as location, circumstance, and time. Despite the existence of such variables, common mechanisms that maintain undifferentiated pools of stem cells appear to exist across different stem cell niches. Our findings that Ang II increases the number of neural stem cells through induction of Nox 4 expression, together with our data showing that elevation of Nox4 levels is associated with increases in superoxide levels and that antioxidant blocking of superoxide supports our hypothesis that an Ang II $\rightarrow$ Nox4 $\rightarrow$ superoxide axis acts as a driver of stem cell proliferation for maintenance of an undifferentiated neural stem cell pool.

Systemic cell proliferation, for example of vascular smooth muscle cells, is known to be stimulated by Ang II through induction of Nox1-generated superoxide [27, 28]. This, together with our demonstration that Ang II induces the proliferation of neural stem cells, suggests 

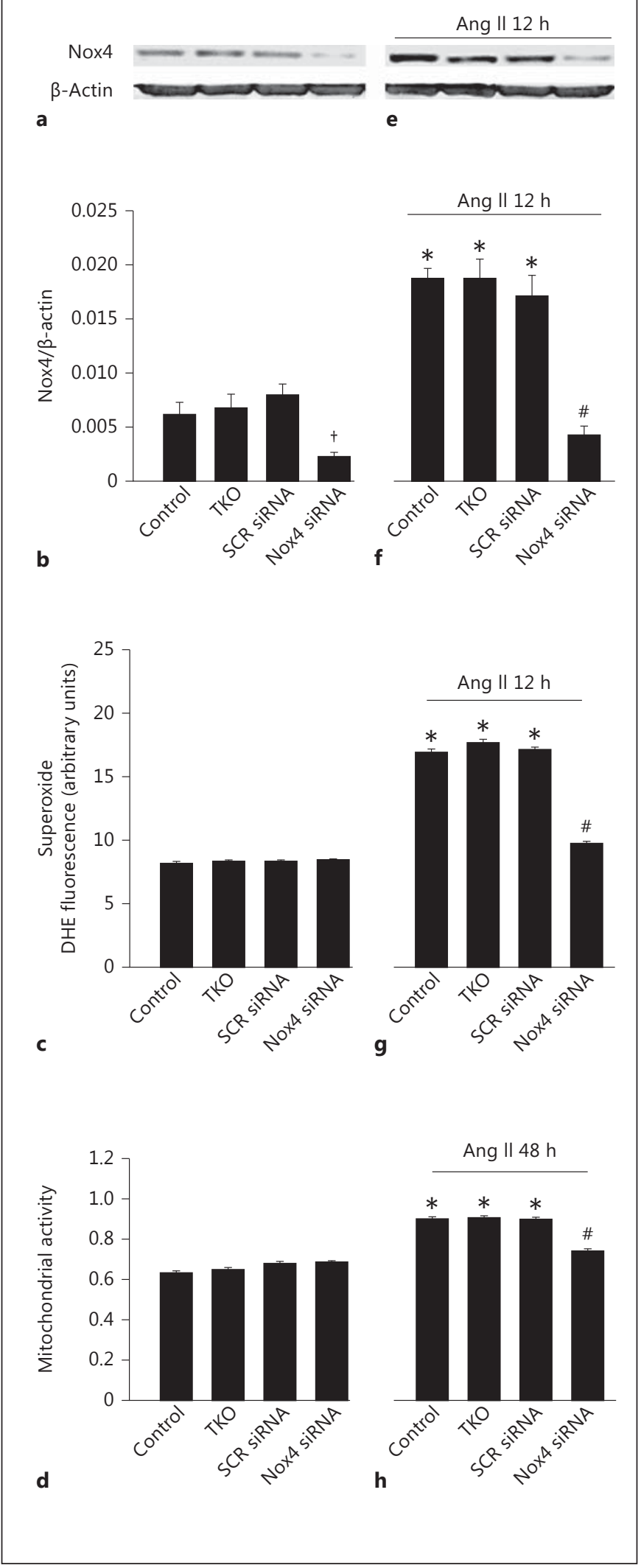

that Ang II acts as a growth factor as it contributes to maintenance of a subpopulation of neural stem cells in undifferentiated pools that may act as reserves in development and stress-induced plasticity in health and disease. In addition, our confirmation of the importance of superoxide generation in Ang II-mediated proliferation of stem cells supports the idea that such superoxide generation has physiologically important roles in the maintenance of cell population balance for replacement of neural cells through recruitment and differentiation of stem cells sequestered in undifferentiated cell pools.

Proliferation-stimulating effects of Ang II in neural stem cells, as previously described in vascular smooth muscle cells, are not necessarily transmitted by a single signaling pathway, but rather occur via context-appropriate downstream signaling mechanisms. Such regulatory mechanism might exist in order to fine-tune responses relative to the diversity of specific cell types as they respond to the common ligand, Ang II. Perhaps due to the nature of Ang II-initiated Nox-mediated responses, which are known to be largely dictated by at least three variables: one is the cell type, the second is the type of stimulus, and the third is the relative abundance of specific Nox isoforms in individual cell types. As an example of cell-type and Nox-isoform diversity, vascular smooth muscle cells $[27,28]$ respond to Ang II with an increase in Nox1 synthesis concurrent with reduction in Nox4 synthesis; in contrast, in neural stem cells we found Ang II-mediated increases in Nox4 synthesis. An additional factor to consider, particularly while studying neural stem cells in culture, is that the balance between prolif-

Fig. 6. Ang II-driven proliferation of C17.2 neural stem cells requires Nox4-generated superoxide. Cells were grown sequentially in complete medium with $15 \%$ serum $(48 \mathrm{~h}$ ), in medium with $0.1 \%$ serum $(24 \mathrm{~h})$, transfected with siRNAs $(24 \mathrm{~h})$, and allowed to recover for $48 \mathrm{~h}$ while being treated for 12 or $48 \mathrm{~h}$ with Ang II. The effect of media only (control), transfection reagent (TKO), scrambled nontargeting siRNA (SCR siRNA), or Nox4 siRNA on: a expression of Nox4 in C17.2 neural stem cells illustrated by Western analysis; b quantification of Nox4 expression; c superoxide levels, and $\mathbf{d}$ proliferation. The effect of media only on C17.2 neural stem cells versus Ang II treatment with transfection reagent (TKO), scrambled nontargeting siRNA (SCR siRNA), or Nox4 siRNA in the presence of Ang II on: e Nox4 expression in C17.2 neural stem cells illustrated by Western analysis; $\mathbf{f}$ quantification of Nox4 expression; $\mathbf{g}$ superoxide levels, and $\mathbf{h}$ proliferation. ${ }^{\dagger} \mathrm{p}<0.01 \mathrm{com}-$ pared to all other culture conditions; ${ }^{*} \mathrm{p}<0.01$ compared with cultures not treated with Ang II; ${ }^{*} \mathrm{p}<0.01$ compared with all other cultures that were treated with Ang II. Data are from three independent experiments with 6 wells per experiment. 
eration and differentiation also depends on cell density, with lower cell densities favoring higher levels of hydrogen peroxide and increased proliferation rates [29].

The importance of Nox-generated ROS stimulatory effects on neural stem cell proliferation are underscored by a report by Le Belle et al. [30] demonstrating that, in vitro, hydrogen peroxide-mediated activation of PI3K/ Akt pathway increases neural stem cell proliferation as well as that, in vivo, apocynin significantly lowers superoxide levels and impairs proliferation in the subventricular zone in mice, as evidenced by the decrease in hydroethidine fluorescence and by the reduction in immunoreactivity for a marker of cell cycle progression, Ki67, respectively. The evidence for the necessity of specific Nox isoforms in maintaining the competency for self-renewal is demonstrated here for Nox4, and, for Nox2, by the observations that neurospheres derived from Nox2deficient mice have (i) diminished endogenous levels of ROS, (ii) significantly reduced capacity for self-renewal, and (iii) exhibit shift in multipotency favoring glial fate [30].

The fact that in human airway smooth muscle cell cultures [31], TGF- $\beta_{1}$ induction of proliferation and hypertrophy involves increased expression of Nox4 [32] when taken together with our finding that TGF- $\beta_{1}$, similarly to Ang II, promotes C17.2 neural stem cell proliferation (see online suppl. fig. $2 \mathrm{~S}$ ), supports our idea that Nox4-generated superoxide production is the common denominator across a spectrum of mechanisms that promote both neural and systemic stem cell proliferation. Although a detailed examination of the TGF- $\beta_{1}$-induced proliferation of neural stem cells is beyond the scope of our current study, we speculate that such proliferation is dependent on the Nox4 pathway as is the case in human airway smooth muscle cells; Nox4 is constitutively expressed in C17.2 neural stem cells and is inducible by Ang II. In addition, there may be multiple signal-transduction steps in the Ang II-AT1 receptor-related production of Nox. For example, application of phorbol esters (PMA) to neural stem cell cultures bypasses the AT1 receptor and directly activates protein kinase $\mathrm{C}$ ( $\mathrm{PKC}$ ) pathways (see online suppl. fig. 2S). This finding supports the previous studies in vascular endothelial cells, which showed that phorbol esters enhance Nox4-mediated production of superoxide [25].

Neural stem cells are known to tolerate relatively high levels of superoxide. This, together with our finding of survival and proliferation of neural stem cells that are producing elevated levels of superoxide (fig. 2), suggests that superoxide generation is a physiological mechanism

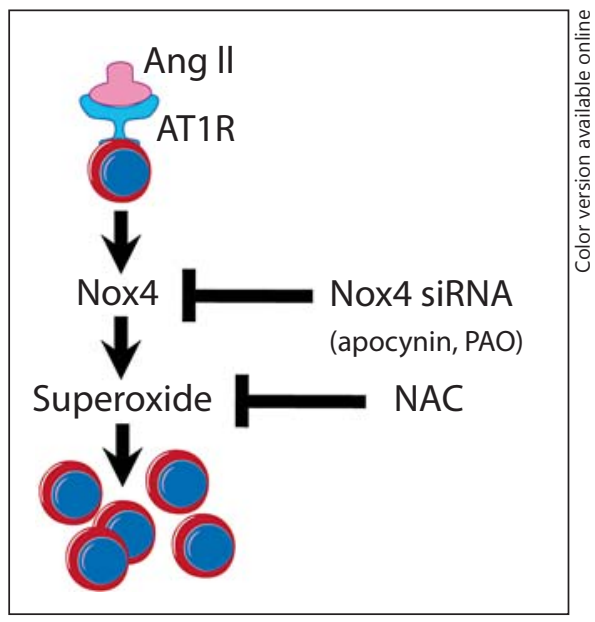

Fig. 7. A conceptualization of Ang II signaling in Nox4-dependent self-renewal of neural stem cells. Ang II binding to its most abundant receptor, AT1 receptor, is known to stimulate signaling cascades leading to activation of various isoforms of Nox in a tissueand cell type-dependent manner $[68,69]$. Here, we show that in C17.2 stem cells, Ang II leads to increased synthesis and activation of Nox4 and thereby enhances superoxide generation toward increased stem cell proliferation. Inhibiting the activity of Nox 4 via Nox4 siRNA targeting, or pharmacologically with inhibitors of Nox (apocynin and PAO), as well as a general antioxidant, NAC, prevented Ang II from increasing superoxide production. The siRNA targeting Nox 4 abolished the following responses to Ang II treatment: (i) increase in Nox4 protein levels, (ii) increase in superoxide production, and (iii) increase in stem cell numbers.

that assures maintenance of stem cells through innate protection against oxidative stress imposed by superoxide. There is evidence that this resistance is related to increases in antioxidant capacity of such cells; for example, they express high levels of key antioxidant enzymes such as glutathione peroxidase and mitochondrial uncoupling protein 2 [33].

In our study, Ang II-induced superoxide acted as a signaling molecule for initiating cell proliferation, suggesting that the observed lag period (minutes to hours) is required for this signal to propagate and initiate cell division; perhaps as a result of de novo protein and nucleic acid synthesis necessary for detectable levels of proliferation. This is consistent with our finding that superoxide is up early $1-12 \mathrm{~h}$ following Ang II stimulation, while proliferation and increased numbers of cells are detected at 12,24 , and $48 \mathrm{~h}$. Examples of early superoxide signaling and later proliferation can be found in the literature. One recent example describes proliferation of vascular smooth muscle cells following a 1-hour exposure to Ang II, at 
which time there was a doubling of superoxide levels. In contrast, there was no upsurge in proliferation until between 24 and $48 \mathrm{~h}$ [34]. In our brain-derived stem cells, we also detected an Ang II-related increase in superoxide at $1 \mathrm{~h}$, and this increase persisted until $12 \mathrm{~h}$ after Ang II. Our finding of marked increases in proliferation at 24 and $48 \mathrm{~h}$ after Ang II is consistent with similar proliferative responses to Ang II in vascular smooth muscle cells [35].

When dopamine neurons are exposed to cytotoxins, they display two waves of superoxide production - in wave one superoxide originates from mitochondrial complexes and in wave two superoxide generation arises from increased expression and activation of Nox 2 in extramitochondrial membranes; this cytotoxin-induced increase in superoxide results in cell killing of such dopamine cells [17]. If these two waves exist in the C17.2 neural stem cells, it may be assumed that rather than being part of the death cascade, superoxide is involved in genesis of stem cells through segregation of Nox 4 activity between mitochondrial and extramitochondrial superoxide production. This is further evidence that superoxide has roles that are circumstance-dependent, that is for maintenance of stem cell pools, superoxide facilitates proliferation rate, while in response to stressful events in mature neurons, superoxide initiates the death cascade. This idea is supported by studies of cardiovascular diseases in which Nox4-generated superoxide has angiogenesis-promoting properties that enhance cardiac survival $[36,37]$.

In further support of the importance of superoxide generation for protection and regeneration of tissues, leukocyte-dependent regeneration of zebrafish tail fin requires Duox-produced hydrogen peroxide, which in addition to its antiseptic actions, sets up a hydrogen peroxide gradient across the margin of the wound - a signal for rapid recruitment of leukocytes which initiate restoration of the epithelial barrier between the injured tissue and the outside environment and pathogens [38]. Moreover, stem cell differentiation, for example in neural, adipose, embryonic, and induced pluripotent stem cells, has been shown to be dependent on superoxide [39-43]. Vis-à-vis the role of the renin-angiotensin system in stem cell differentiation, Ang II/AT1 receptor-dependent generation of superoxide promotes differentiation of induced pluripotent stem cells to mesodermal progenitor cells via JAK/STAT pathway [40] and Nox4-produced hydrogen peroxide promotes differentiation embryonic stem cells to smooth muscle cells [44].

When treated with Ang II, neural stem cells generate superoxide (DHE, red) in mitochondria, identified here by MitoTracker Green, suggesting that superoxide may arise from either mitochondrial electron transport complexes or from mitochondrial Nox 4, or both. Contribution of superoxide from extramitochondrial sites, including that in the nucleus, endoplasmic reticulum, and cell and nuclear membranes may be from Nox4, as well as, according to our findings by RT-PCR, from Nox3, Duox1, and Duox2. The DHE fluorescence (ethidium bromide) in the nucleus suggests that superoxide may be generated in the nucleus, may have an extranuclear source that then enters the nucleus, or may be a combination of the two.

Two common nonisoform-selective inhibitors of Nox (PAO and apocynin) are known to downregulate Noxdriven superoxide generation $[45,46]$. Their use here demonstrates the essential nature of Nox isoforms in Ang II-driven generation of superoxide both mitochondrially and extramitochondrially. This requirement for Nox for Ang II-induced superoxide generation, together with the requirement for superoxide for proliferation of neural stem cells, underscores the importance of the Ang II $\rightarrow$ Nox $\rightarrow$ superoxide pathway for generation of undifferentiated stem cells for maintenance of neural stem cell niches that may be available for tissue development and for tissue repair after maladaptive events. Although the 7-hour exposure of C17.2 cell cultures to $10 \mu \mathrm{M}$ apocynin dramatically reduced the production of superoxide, apocynin did not result in cell death in these cultures (see online suppl. fig. 1S), regardless of whether it was added alone or in a combination with Ang II - a finding that is consistent with the observation that even higher concentration of apocynin $(100 \mu \mathrm{M})$ applied for a longer time (24 h) had no effect on survival of cultured microglia [47].

The relative abundance of the specific Nox isoforms might be a signature identifying specific tissue cell types $[11,48-50]$. Our finding of a variation in the levels of expression of Nox isoforms in C17.2 neural stem cells at both the mRNA and protein levels, e.g. Nox $<$ Duox $2<$ Nox $3<$ Duox $1<$ Nox 4 , suggests that such variations may be part of the proof of identity of specific stem cell populations. Our observation that Ang II induces synthesis of Nox4 protein in neural stem cells is consistent with the idea that Nox4 is a highly inducible Nox isoform in a number of tissues. For example, stimulus/tissue combinations that increase de novo production of Nox4 include: (i) hypoxia/pulmonary arterial smooth muscle cells $[51,52]$, (ii) TGF- $\beta_{1} /$ cardiac fibroblasts and hepatocytes $[53,54]$, and (iii) cannabidiol (a nonpsychoactive cannabinoid)/human leukemia cells [55].

Substantiation of a predicted two-pronged consequence of Nox 4 siRNA targeting: (i) a decrease in an Ang II-Nox4-mediated rise in superoxide generation was sup- 
pressed proportionally to the degree of suppression of Nox 4 by siRNA, and (ii) stem cell proliferation was suppressed proportionally to superoxide generation. These findings are consistent with the idea that the development and maintenance of stem cell reservoirs in the brain are dependent on superoxide production engendered by Ang II induction of Nox 4 expression. Moreover, the finding of relatively low levels of superoxide in growth-arrested cells and that the number of viable stem cells was not altered by reducing Nox4 expression suggest that Ang II induction is part of the normal neural stem cell generation necessary for CNS development, and as a consequence of external or internal stresses may call for generation of Nox4induced superoxide for maintenance and proliferation of cells in niches of neural stem cell pools.

Although we did not perform assays of differentiation per se and, therefore, cannot exclude the possibility that in addition to proliferation of neural stem cells, some proliferation of neural progenitors may have occurred, we followed previous protocols [56] to minimize differentiation of our C17.2 cells. All cells were cultured in low serum $(0.1 \%)$ that was not supplemented with either N2 supplement or growth factors such as nerve growth factor and brain-derived neurotrophic factor. This strategy resulted in proliferation at both 3 and 4 days, but not at 5 days, after plating, times prior to the appearance of differentiated cells at 7 days after plating $[56,57]$. Furthermore, the morphology of C17.2 cells in such deficient medium was predominantly round or oblong and free of neurites, which is consistent with the appearance of neural stem cells rather than neurite-bearing neurons.

The differential response to high levels of Ang II-induced superoxide versus the low levels used here provide evidence to support the importance of maintaining a balance between a minimum level of Ang II induction of superoxide, necessary for self-renewal of the stem cell pool for genesis of new neurons, and a higher level of superoxide that leads to oxidative stress, neuroinflammation, and a reduction in neurogenesis. In support of this idea, there is substantial elevation in Ang II type 1 receptor-mediated signaling and superoxide generation in a mouse model of Parkinson's disease [58], and this elevation is accompanied by a reduction in neurogenesis in these mice [59], in oxidative stress, and in neuronal loss. Thus, the potential exists for modulating Ang II signaling, for example through the use of Ang II receptor blockers (ARBs) that normalize angiotensin activity and restore neurogenesis to physiological levels in disease states involving neuroinflammation as demonstrated in a comparable study using indomethacin-produced inflammatory

Nox4-Generated Superoxide Drives Ang II-Induced Neural Stem Cell Proliferation blockade for the restoration of neurogenesis in adult hippocampus in mice exposed to an inflammagen, lipopolysaccharide [60]. As further evidence, in a model of radiation-induced impairment of neurogenesis, treatment with ramipril, an Ang I-converting enzyme (ACE) inhibitor that suppresses Ang II production, reverses the radiation-induced reduction in progenitor proliferation resulting in restoration of hippocampal neurogenesis [61]. These studies are consistent with our findings showing that Ang II stimulates neural stem cell proliferation, while ACE inhibition reduces neurogenesis, suggesting a need for maintaining the optimal level of Ang II for maintenance of neurogenesis. This may be especially important in neurological conditions exhibiting oxidative stress and neuroinflammation.

We conclude that the dependency of neural stem cells on Ang II-Nox4-mediated increases in superoxide generation for self-renewal may have broad implications for normal brain development as well as for maintenance of cellular homeostasis in health and in response to neuropathological changes. The latter include chronic neuroinflammatory conditions accompanied by elevated angiotensin system activity such as: (i) neurogenic hypertension [62-64], (ii) Alzheimer's disease [65], (iii) Parkinson's disease [66], and (iv) multiple sclerosis [67]. Therefore, in health as well as in disease, irregular Ang II levels and superoxide generation may disturb the normal redox balance, which controls neural stem cell proliferation and neuronal survival, and as such should be considered when deciphering mechanistic controls responsible for maintaining optimal angiotensin actions. Because of the importance of such actions, Ang II-driven signaling pathways may constitute novel targets for disease-modifying therapeutics.

\section{Acknowledgements}

The authors thank Dr. Wenbo Zhou of the University of Colorado Denver for providing C17.2 cells and Kaili Weil and Miranda Stark of Carl Zeiss MicroImaging, Inc. for assistance with confocal microscopy. This work was supported by the National Institutes of Health grants: AA016654 (W.M.Z.), HL64917 (M.D.), and AG12411 (W.S.T.G. and S.W.B.).

Dev Neurosci 2013;35:293-305

DOI: $10.1159 / 000350502$ 


\section{References}

$>1$ Bergstrom T, Forsberg-Nilsson K: Neural stem cells: brain building blocks and beyond. Ups J Med Sci 2012;117:132-142.

$>2$ Ming GL, Song H: Adult neurogenesis in the mammalian brain: significant answers and significant questions. Neuron 2011;70:687702 .

$\checkmark 3$ Kempermann G: New neurons for 'survival of the fittest'. Nat Rev Neurosci 2012;13:727736.

4 Mohamed A, I, Mitra A, Basu A: Epigenetic regulation of self-renewal and fate determination in neural stem cells. J Neurosci Res 2012; 90:529-539.

$\checkmark 5$ Drago J, Murphy M, Carroll SM, Harvey RP, Bartlett PF: Fibroblast growth factor-mediated proliferation of central nervous system precursors depends on endogenous production of insulin-like growth factor I. Proc Natl Acad Sci USA 1991;88:2199-2203.

6 Reynolds BA, Tetzlaff W, Weiss S: A multipotent EGF-responsive striatal embryonic progenitor cell produces neurons and astrocytes. J Neurosci 1992;12:4565-4574.

7 Aguirre A, Rubio ME, Gallo V: Notch and EGFR pathway interaction regulates neural stem cell number and self-renewal. Nature 2010;467:323-327.

$>8$ Rodriguez-Pallares J, Quiroz CR, Parga JA, Guerra MJ, Labandeira-Garcia JL: Angiotensin II increases differentiation of dopaminergic neurons from mesencephalic precursors via angiotensin type 2 receptors. Eur J Neurosci 2004;20:1489-1498.

$\checkmark 9$ Sodhi CP, Kanwar YS, Sahai A: Hypoxia and high glucose upregulate AT1 receptor expression and potentiate ANG II-induced proliferation in VSM cells. Am J Physiol Heart Circ Physiol 2003;284:H846-H852.

-10 Yoneyama M, Kawada K, Gotoh Y, Shiba T, Ogita K: Endogenous reactive oxygen species are essential for proliferation of neural stem/ progenitor cells. Neurochem Int 2010;56: $740-746$.

$\checkmark 11$ Katsuyama M: NOX/NADPH oxidase, the superoxide-generating enzyme: its transcriptional regulation and physiological roles. J Pharmacol Sci 2010;114:134-146.

-12 Pachucki J, Wang D, Christophe D, Miot F: Structural and functional characterization of the two human ThOX/Duox genes and their 5 '-flanking regions. Mol Cell Endocrinol 2004;214:53-62.

13 Kawahara T, Quinn MT, Lambeth JD: Molecular evolution of the reactive oxygen-generating NADPH oxidase (Nox/Duox) family of enzymes. BMC Evol Biol 2007;7:109.

14 Geiszt M, Kopp JB, Varnai P, Leto TL: Identification of renox, an $\mathrm{NAD}(\mathrm{P}) \mathrm{H}$ oxidase in kidney. Proc Natl Acad Sci USA 2000;97: 8010-8014.

-15 Cross AR, Segal AW: The NADPH oxidase of professional phagocytes - prototype of the NOX electron transport chain systems. Biochim Biophys Acta 2004;1657:1-22.
16 Wingler K, Hermans J, Schiffers P, Moens A, Paul M, Schmidt H: NOX1, 2, 4, 5: counting out oxidative stress. Br J Pharmacol 2011;164: 866-883.

17 Zawada WM, Banninger GP, Thornton J, Marriott B, Cantu D, Rachubinski AL, Das M, Griffin WS, Jones SM: Generation of reactive oxygen species in 1-methyl-4-phenylpyridinium $\left(\mathrm{MPP}^{+}\right)$-treated dopaminergic neurons occurs as an NADPH oxidase-dependent two-wave cascade. J Neuroinflammation 2011;8:129.

18 Ryder EF, Snyder EY, Cepko CL: Establishment and characterization of multipotent neural cell lines using retrovirus vector-mediated oncogene transfer. J Neurobiol 1990;21: 356-375.

19 Rothe G, Valet G: Flow cytometric analysis of respiratory burst activity in phagocytes with hydroethidine and $2^{\prime}, 7^{\prime}$-dichlorofluorescin. J Leukoc Biol 1990;47:440-448.

20 Chabrashvili T, Kitiyakara C, Blau J, Karber A, Aslam S, Welch WJ, Wilcox CS: Effects of ANG II type 1 and 2 receptors on oxidative stress, renal NADPH oxidase, and SOD expression. Am J Physiol Regul Integr Comp Physiol 2003;285:R117-R124.

21 Rao GN, Berk BC: Active oxygen species stimulate vascular smooth muscle cell growth and proto-oncogene expression. Circ Res 1992;70: 593-599.

22 Ushio-Fukai M, Zafari AM, Fukui T, Ishizaka $\mathrm{N}$, Griendling KK: p22phox is a critical component of the superoxide-generating NADH/ NADPH oxidase system and regulates angiotensin II-induced hypertrophy in vascular smooth muscle cells. J Biol Chem 1996;271: 23317-23321.

23 Lee CF, Qiao M, Schroder K, Zhao Q, Asmis $\mathrm{R}$ : Nox4 is a novel inducible source of reactive oxygen species in monocytes and macrophages and mediates oxidized low density lipoprotein-induced macrophage death. Circ Res 2010;106:1489-1497.

24 Ambasta RK, Kumar P, Griendling KK, Schmidt HH, Busse R, Brandes RP: Direct interaction of the novel Nox proteins with p22phox is required for the formation of a functionally active NADPH oxidase. J Biol Chem 2004;279:45935-45941.

25 Kuroda J, Nakagawa K, Yamasaki T, Nakamura K, Takeya R, Kuribayashi F, ImajohOhmi S, Igarashi K, Shibata Y, Sueishi K, Sumimoto $\mathrm{H}$ : The superoxide-producing NAD(P)H oxidase Nox4 in the nucleus of human vascular endothelial cells. Genes Cells 2005;10:1139-1151.

26 Graham KA, Kulawiec M, Owens KM, Li X, Desouki MM, Chandra D, Singh KK: NADPH oxidase 4 is an oncoprotein localized to mitochondria. Cancer Biol Ther 2010;10:223-231.

27 Lassegue B, Sorescu D, Szocs K, Yin Q, Akers M, Zhang Y, Grant SL, Lambeth JD, Griendling KK: Novel gp91(phox) homologues in vascular smooth muscle cells: nox1 mediates angiotensin II-induced superoxide formation and redox-sensitive signaling pathways. Circ Res 2001;88:888-894.

-28 Suh YA, Arnold RS, Lassegue B, Shi J, Xu X, Sorescu D, Chung AB, Griendling KK, Lambeth JD: Cell transformation by the superoxide-generating oxidase Mox1. Nature 1999; 401:79-82.

29 Limoli CL, Rola R, Giedzinski E, Mantha S, Huang TT, Fike JR: Cell-density-dependent regulation of neural precursor cell function. Proc Natl Acad Sci USA 2004;101:1605216057.

30 Le Belle JE, Orozco NM, Paucar AA, Saxe JP, Mottahedeh J, Pyle AD, Wu H, Kornblum HI: Proliferative neural stem cells have high endogenous ROS levels that regulate self-renewal and neurogenesis in a PI3K/Akt-dependent manner. Cell Stem Cell 2011;8:59-71.

-31 Sturrock A, Huecksteadt TP, Norman K, Sanders K, Murphy TM, Chitano P, Wilson K, Hoidal JR, Kennedy TP: Nox4 mediates TGF$\beta_{1}$-induced retinoblastoma protein phosphorylation, proliferation, and hypertrophy in human airway smooth muscle cells. Am J Physiol Lung Cell Mol Physiol 2007; 292:L1543-L1555.

32 Green DE, Murphy TC, Kang BY, Kleinhenz JM, Szyndralewiez C, Page P, Sutliff RL, Hart CM: The Nox4 inhibitor, GKT137831, attenuates hypoxia-induced pulmonary vascular cell proliferation. Am J Respir Cell Mol Biol 2012;47:718-726.

33 Madhavan L, Ourednik V, Ourednik J: Increased 'vigilance' of antioxidant mechanisms in neural stem cells potentiates their capability to resist oxidative stress. Stem Cells 2006; 24:2110-2119.

34 Valente AJ, Yoshida T, Murthy SN, Sakamuri SS, Katsuyama M, Clark RA, Delafontaine P, Chandrasekar B: Angiotensin II enhances AT1-Nox1 binding and stimulates arterial smooth muscle cell migration and proliferation through AT1, Nox1, and interleukin-18. Am J Physiol Heart Circ Physiol 2012; 303:H282-H296.

-35 Fang L, Chen MF, Xiao ZL, Yu GL, Chen XB, Xie XM: The effect of endothelial progenitor cells on angiotensin II-induced proliferation of cultured rat vascular smooth muscle cells. J Cardiovasc Pharmacol 2011;58:617-625.

36 Schroder K, Zhang M, Benkhoff S, Mieth A, Pliquett R, Kosowski J, Kruse C, Ludike P, Michaelis UR, Weissmann N, Dimmeler S, Shah AM, Brandes RP: Nox4 is a protective reactive oxygen species generating vascular NADPH oxidase. Circ Res 2012;110:12171225.

37 Zhang M, Brewer AC, Schroder K, Santos CX, Grieve DJ, Wang M, Anilkumar N, Yu B, Dong X, Walker SJ, Brandes RP, Shah AM: NADPH oxidase-4 mediates protection against chronic load-induced stress in mouse hearts by enhancing angiogenesis. Proc Natl Acad Sci USA 2010;107:18121-18126. 
-38 Niethammer P, Grabher C, Look AT, Mitchison TJ: A tissue-scale gradient of hydrogen peroxide mediates rapid wound detection in zebrafish. Nature 2009;459:996-999.

- 39 Kim JH, Song SY, Park SG, Song SU, Xia Y, Sung JH: Primary involvement of NADPH oxidase 4 in hypoxia-induced generation of reactive oxygen species in adipose-derived stem cells. Stem Cells Dev 2012;21:22122221.

-40 Ishizuka T, Goshima H, Ozawa A, Watanabe Y: Effect of angiotensin II on proliferation and differentiation of mouse induced pluripotent stem cells into mesodermal progenitor cells. Biochem Biophys Res Commun 2012; 420:148-155.

-41 Buggisch M, Ateghang B, Ruhe C, Strobel C, Lange S, Wartenberg M, Sauer H: Stimulation of ES-cell-derived cardiomyogenesis and neonatal cardiac cell proliferation by reactive oxygen species and NADPH oxidase. J Cell Sci 2007; 120:885-894.

42 Wang N, Xie K, Huo S, Zhao J, Zhang S, Miao $\mathrm{J}$ : Suppressing phosphatidylcholine-specific phospholipase C and elevating ROS level, NADPH oxidase activity and Rb level induced neuronal differentiation in mesenchymal stem cells. J Cell Biochem 2007;100:15481557.

43 Zhou W, Freed CR: Adenoviral gene delivery can reprogram human fibroblasts to induced pluripotent stem cells. Stem Cells 2009;27: 2667-2674.

-44 Xiao Q, Luo Z, Pepe AE, Margariti A, Zeng L, $\mathrm{Xu}$ Q: Embryonic stem cell differentiation into smooth muscle cells is mediated by Nox4-produced $\mathrm{H}_{2} \mathrm{O}_{2}$. Am J Physiol Cell Physiol 2009;296:C711-C723.

-45 Le C, V, Maridonneau-Parini I: Complete and reversible inhibition of $\mathrm{NADPH}$ oxidase in human neutrophils by phenylarsine oxide at a step distal to membrane translocation of the enzyme subunits. J Biol Chem 1995;270: 2067-2073.

46 Stefanska J, Pawliczak R: Apocynin: molecular aptitudes. Mediators Inflamm 2008;2008: 106507.

$\checkmark 47$ Lull ME, Levesque S, Surace MJ, Block ML: Chronic apocynin treatment attenuates $\beta$-amyloid plaque size and microglial number in hAPP(751)(SL) mice. PLoS One 2011; 6:e20153.

48 Krause KH: Tissue distribution and putative physiological function of NOX family NADPH oxidases. Jpn J Infect Dis 2004; 57:S28-S29.
49 Sorce S, Krause KH: NOX enzymes in the central nervous system: from signaling to disease. Antioxid Redox Signal 2009;11:2481-2504.

-50 Katsuyama M, Matsuno K, Yabe-Nishimura C: Physiological roles of NOX/NADPH oxidase, the superoxide-generating enzyme. J Clin Biochem Nutr 2012;50:9-22.

51 Mittal M, Roth M, Konig P, Hofmann S, Dony E, Goyal P, Selbitz AC, Schermuly RT, Ghofrani HA, Kwapiszewska G, Kummer W, Klepetko W, Hoda MA, Fink L, Hanze J, Seeger W, Grimminger F, Schmidt HH, Weissmann N: Hypoxia-dependent regulation of nonphagocytic NADPH oxidase subunit NOX4 in the pulmonary vasculature. Circ Res 2007;101:258-267.

52 Diebold I, Petry A, Hess J, Gorlach A: The NADPH oxidase subunit NOX4 is a new target gene of the hypoxia-inducible factor-1. Mol Biol Cell 2010;21:2087-2096.

53 Cucoranu I, Clempus R, Dikalova A, Phelan PJ, Ariyan S, Dikalov S, Sorescu D: NAD (P)H oxidase-4 mediates transforming growth factor- $\beta_{1}$-induced differentiation of cardiac fibroblasts into myofibroblasts. Circ Res 2005;97:900-907.

54 Carmona-Cuenca I, Roncero C, Sancho P, Caja L, Fausto N, Fernandez M, Fabregat I: Upregulation of the NADPH oxidase NOX4 by TGF- $\beta$ in hepatocytes is required for its pro-apoptotic activity. J Hepatol 2008;49: 965-976.

-55 McKallip RJ, Jia W, Schlomer J, Warren JW, Nagarkatti PS, Nagarkatti M: Cannabidiolinduced apoptosis in human leukemia cells: a novel role of cannabidiol in the regulation of p22phox and Nox4 expression. Mol Pharmacol 2006;70:897-908.

56 Lundqvist J, Andaloussi-Lilja JE, Svensson C, Dorfh HG, Forsby A: Optimisation of culture conditions for differentiation of C17.2 neural stem cells to be used for in vitro toxicity tests. Toxicol In Vitro 2012 (E-pub ahead of print).

-57 Kim SJ, Son TG, Kim K, Park HR, Mattson MP, Lee J: Interferon- $\gamma$ promotes differentiation of neural progenitor cells via the JNK pathway. Neurochem Res 2007;32:13991406.

58 Grammatopoulos TN, Jones SM, Ahmadi FA, Hoover BR, Snell LD, Skoch J, Jhaveri VV, Poczobutt AM, Weyhenmeyer JA, Zawada WM: Angiotensin type 1 receptor antagonist losartan, reduces MPTP-induced degeneration of dopaminergic neurons in substantia nigra. Mol Neurodegener 2007;2:1.
59 L'Episcopo F, Tirolo C, Testa N, Caniglia S, Morale MC, Deleidi M, Serapide MF, Pluchino S, Marchetti B: Plasticity of subventricular zone neuroprogenitors in MPTP (1-methyl4-phenyl-1,2,3,6-tetrahydropyridine) mouse model of Parkinson's disease involves cross-talk between inflammatory and $\mathrm{Wnt} / \beta$ catenin signaling pathways: functional consequences for neuroprotection and repair. J Neurosci 2012;32:2062-2085.

60 Monje ML, Toda H, Palmer TD: Inflammatory blockade restores adult hippocampal neurogenesis. Science 2003;302:1760-1765.

-61 Jenrow KA, Brown SL, Liu J, Kolozsvary A, Lapanowski K, Kim JH: Ramipril mitigates radiation-induced impairment of neurogenesis in the rat dentate gyrus. Radiat Oncol 2010;5:6.

62 Paton JF, Raizada MK: Neurogenic hypertension. Exp Physiol 2010 95:569-571.

63 Zubcevic J, Waki H, Raizada MK, Paton JF: Autonomic-immune-vascular interaction: an emerging concept for neurogenic hypertension. Hypertension 2011;57:1026-1033.

64 Jun JY, Zubcevic J, Qi Y, Afzal A, Carvajal JM, Thinschmidt JS, Grant MB, Mocco J, Raizada MK: Brain-mediated dysregulation of the bone marrow activity in angiotensin II-induced hypertension. Hypertension 2012;60: 1316-1323.

65 Miners S, Ashby E, Baig S, Harrison R, Tayler H, Speedy E, Prince JA, Love S, Kehoe PG: Angiotensin-converting enzyme levels and activity in Alzheimer's disease: differences in brain and CSF ACE and association with ACE1 genotypes. Am J Transl Res 2009;1: 163-177.

-66 Konings $\mathrm{CH}$, Kuiper MA, Bergmans PL, Grijpma AM, van Kamp GJ, Wolters EC: Increased angiotensin-converting enzyme activity in cerebrospinal fluid of treated patients with Parkinson's disease. Clin Chim Acta 1994;231:101-106.

67 Constantinescu CS, Goodman DB, Grossman RI, Mannon LJ, Cohen JA: Serum angiotensin-converting enzyme in multiple sclerosis. Arch Neurol 1997;54:1012-1015.

68 Anilkumar N, Weber R, Zhang M, Brewer A, Shah AM: Nox4 and Nox2 NADPH oxidases mediate distinct cellular redox signaling responses to agonist stimulation. Arterioscler Thromb Vasc Biol 2008;28:1347-1354.

69 Chabrashvili T, Kitiyakara C, Blau J, Karber A, Aslam S, Welch WJ, Wilcox CS: Effects of ANG II type 1 and 2 receptors on oxidative stress, renal NADPH oxidase, and SOD expression. Am J Physiol Regul Integr Comp Physiol 2003;285:R117-R124.
Nox4-Generated Superoxide Drives Ang II-Induced Neural Stem Cell Proliferation
Dev Neurosci 2013;35:293-305 DOI: $10.1159 / 000350502$ 